\title{
Bagaimana Gizi Sejak Massa Konsepsi Dapat Mempengaruhi Kesehatan Biologis Anak?
}

\author{
How Nutrition from Conception can Impact a Child's Biological Health?
}

\author{
Trias Mahmudiono ${ }^{1}$
}

\begin{abstract}
ABSTRAK
Latar Belakang: gizi yang baik bagi ibu sejak masa pra konsepsi dan konsepsi merupakan persiapan yang penting untuk kesehatan janin dan anak dimasa dating.

Tujuan: tujuan dalam penulisan literature review ini adalah untuk menjelaskan secara argumentative bagaimana gizi sejak masa konsepsi dapat mempengaruhi kesehatan biologis anak.

Pembahasan: hasil literature review menunjukkan bukti bahwa gizi sejak masa konsepsi dapat mempengaruhi kesehatan biologis anak. Beberapa artikel menunjukkan mekanisme yang menjelaskan kemungkinan mekanisme pengaruh gizi saat konsepsi terhadap kesehatan biologis anak dimasa datang seperti halnya Barker Hyphothesis atau fetal programming. Namun begitu, data yang diperoleh hingga saat ini masih belum meyakinkan sepenuhnya. Untuk itu perlu dikembangkan penelitian yang panjang atau longitudinal dan eksperimental yang dapat menggaransi kebenaran teori tersebut.

Kesimpulan: argumentasi bahwa gizi sejak masa konsepsi diyakini berpengaruh terhadap kesehatan biologis anak dimasa depan semakin menguat dalam literature terkini walaupun bukti hasil penelitian eksperimental masih perlu banyak diakumulasikan untuk memastikan kebenarannya.
\end{abstract}

Kata Kunci: gizi, massa konsepsi, anak, kesehatan biologis.

\begin{abstract}
Background: good nutrition for mothers since pre-conception and conception is an important preparation for the health of the fetus and the child in the future.

Objective: The purpose in writing this literature review is to explain argumentatively how nutrition from the time of conception can affect the child's biological health.

Discussion: The results of the literature review show evidence that nutrition from the time of conception can affect the child's biological health. Several articles show a mechanism that explains the possible mechanisms of nutritional influence as conception on the child's biological health as in the future as Barker Hyphothesis or fetal programming. However, the data obtained to date is still not fully convincing. It is necessary to develop a long or longitudinal and experimental research that can guarantee the truth of the theory.

Conclusion: the argument that nutrition from the time of conception is believed to affect the biological health of children in the future is increasingly stronger in the current literature although evidence of experimental research results still need to be accumulated to ensure the truth.
\end{abstract}

Keywords: nutrition, mass of conception, child, biological health. 
*Koresponden:

trias-m@fkm.unair.ac.id

${ }^{1}$ Departemen Gizi Kesehatan, Fakultas Kesehatan Masyarakat,

Universitas Airlangga, Surabaya, Indonesia

\section{INTRODUCTION}

Investation that was the most cost effective and critical for child growth was believed to be related to nutrition. During the first thousand days of life suitable nutrition condition since in utero until the second birthday argued to have high impact on linear growth, cognitive function and intergenerational poverty alleviation. The growth of an embryo and fetus is beginning with proliferation, organization, and differentiation followed up by organs and tissues maturation that are completely functional ${ }^{1}$. Several factors are influential for the growth such as the embryo genetic profile, the maternal-placental-fetal unit, sufficient oxygen and nutrient for the development of the fetus, prenatal weight, additional weight obtained during pregnancy ${ }^{1}$. In the late 1980s Barker postulates the fetal origins hypothesis that maternal nutritional condition during pregnancy "program" the fetus for the development of chronic disease later in life ${ }^{2}$. Adult disease originates through growth during proliferation in the fetus and associated with perpetual changes in endocrine and metabolic process ${ }^{3}$. Both micro- and macrosomia, and also prematurity, may contribute to type 2 diabetes, obesity, hypertension, metabolic syndrome, and artherosclerosis development ${ }^{4}$. The health status of the mother as well as her lifestyle was believed, both under- and over-nutrition, arguably pivotal for metabolic programing for the next generation.

\section{DISCUSSIONS}

\section{Gestational Weight Gain}

Several lifestyle recommendations especially for mothers from conception arguably will improve the optimal health outcomes in the child at age 5-10 years after birth. Targeting pregnant women considered impactful since they appear to be motivated to improve their diet during pregnancy ${ }^{5,6}$. Beter outcome for mother and child could be achieved when women weight within the normal BMI range prior to conception and able to maintain or gain weight within ranges suggested by the Institute of Medicine (IOM) for ideal weight for pregnant women ${ }^{7}$. In the more affluent populations where the prevalence of maternal overweight and obesity was relatively high, we recommend healthy lifestyle that incorporated healthy diet and physical activity. This could be achieved adherence healthful dietary pattern such as Mediterranean Diet, Dietary Approach to Stop Hypertension (DASH) or compliance towards Healthy Eating Index (HEI). These healthy dietary approaches have been associated with a $24 \%$ to $26 \%$ decrease in the threat of gestational diabetes mellitus (GDM) ${ }^{7}$. In a low risk pregnancy, moderately intense activity does not increase risk of low birth weight (LBW), preterm delivery, or miscarriage ${ }^{7}$. Systematic review and meta-analysis of controlled trials on behavioral interventions in the form of diet and physical activity for weight management in pregnancy showed decrease in gestational weight gain even though the overall effect size found no significant difference ${ }^{8}$. On other meta-analysis of intervention trials indicated a lower gestational weight gain (GWG) in the intervention groups, with a standardized mean difference of -0.22 unit $(95 \% \mathrm{Cl}:-0.38$,0.05 units) ${ }^{9}$. The intervention was based on physical activity and dietary counseling, usually combined with supplementary weight monitoring. It is important to maintain GWG at the recommended range to prevent macrosomia for the newborn. One of the risk factor for diabetes and cardiovascular related 
diseases later in life was related to macrosomia. Baby born having macrosomia increased the risk of overweight and obesity, disturbance in glucose and insulin its secretion. Hyperglycemia could be developed due to high level of glucose in pregnant women that might lead to stimulation of fetal beta-cells to secret insulin ${ }^{2}$. In addition, the risk of maternal overweight and excess GWG was related to the role of leptin. Adipose tissues secreted leptin that served as a sensor to the body fat. Leptin is secreted in level that directly correlates with body fat stores. It acts as an anorexogenic hormone in the brain, controlling feeding behavior by specifically decreasing appetite and therefore food intake 1. Fetal hyperleptinemia might be induced from maternal obesity or maternal weightgain during pregnancy and arguably have significant influences on the fetal hypothalamus and on energy balance in the later life ${ }^{5}$. Among women at higher risk of exceeding the GWG goals as proposed by IOM in 2009, recommendation to follow a low GI diet might be particularly beneficial as a primary prevention of above mention fetal origin hypothesis ${ }^{5}$.

We also recommend mother to check the pregnancy for risk of gestational diabetes mellitus (GDM). If the mothers have a mild to high risk of GDM we recommend adjusting lifestyle especially in the diet of food with low glycemic index ${ }^{5}$. Environmental exposure in utero such as high glucose (in mother with gestational diabetes mellitus) or maternal obesity and overfeeding during pregnancy alter the programming of genes by epigenetic markings, resulting in a long-term imprint on gene expression last into adulthood ${ }^{1}$. In animal study, induced GDM was lead to adiposity accumulation in the offspring. When the next generation is female, she has high chance of developing GDM and when pregnant the cycle of intergenerational diabetes and obesity will be perpetuated ${ }^{10}$. Randomized controlled trial with intervention consisting of dietary advice, blood glucose monitoring and if deemed required, insulin therapysuccessfully reduced macrosomia at birth which considered one of the pathway where fetal origin of adult disease might take place ${ }^{10}$.

\section{Insuline Restriction}

In the developing countries where maternal malnutrition still persisted, the recommendation was emphasize on improving variety of food consumed to meet nutrient need especially protein and folic acid and consuming sufficient calories to support recommended weight gain. Folic acid has long been acknowledged as influential nutrient pre and during pregnancy to prevent neural tube defect ${ }^{7,11}$. Inadequate intrauterine nutrient supply brings information of adverse life conditions in the extra-uterine environment; it may enable to re-program metabolic pathways of the growing conceptus to prepare it to the shortage of food in later life. Forming the thrifty phenotype, that is beneficial under scarcity conditions, is usually detrimental in the case of eventual later abundance and may results in obesity and metabolic syndrome ${ }^{4}$. As insulin is a growth factor during fetal life, the decrease in its action leads to the restriction of development for of such organs as skeletal muscles, pancreas or kidneys. This in turns enables redistribution of important nutrients for the needs of development of key body parts, such as the brain. This mechanism seems to be particularly important under the condition of inadequate food supply during pregnancy or in the case of placental insufficiency. The enhanced risk of metabolic syndrome development in subjects born with IUGR may be also related to the over-activation of the hypothalamo-pituary-adrenal (HPA) axis ${ }^{4}$. Prenatal exposure to protein-restricted diet may influence activity of HPA axis and may impair kidney development in the fetus ${ }^{4}$. Hence, our recommendation for sufficient protein intake for pregnant women will lower the risk of fetal origin of adult disease through preventing over-activation of HPA axis.

\section{IUGR}

For both mothers from either developed and developing countries, increased consumption of food rich in antioxidant will also be recommended along with 
limiting cholesterol intake as well as smoking cessation during pregnancy. It was demonstrated that IUGR infants were characterized by increased oxidative stress compare to infants with normal weight ${ }^{2}$. Furthermore, newborn with IUGR has reduced level of antioxidant and antioxidant enzyme activity while the lipid peroxidation was augmented ${ }^{4}$. Maternal hypercholesterolemia and maternal smoking during pregnancy was known to induce oxidative stress ${ }^{2}$. With increased intake of anti-oxidant, it is believed that the gestational oxidative stress can be minimized. In animal model, maternal supplementation of folic acid, B12, and omega 3 fatty acid significantly reduce the brain oxidative stress in the offspring ${ }^{12}$. When mothers were following the recommendation prenatal and during pregnancy, the optimal health outcomes in the child at age 10 (relative to peers) would be normal BMI relatively to their age and low risk factor for metabolic syndrome such as normal systolic blood pressure. These arguments were built on the assumption that the fetal origin hypothesis postulated by Barker and colleague was true. Barker presented epidemiological studies that link measures of maternal nutrition and childhood blood pressure at age 10-12 in Jamaica that link diet during pregnancy to blood pressure at age 40 in Aberdeen, Scotland ${ }^{2}$. In Jerusalem Perinatal Study association between measures of maternal nutrition and blood pressure in the offspring was statistically significant but no significant relationship was observed between the offspring birth weight and blood pressure 2. Another cohort study in Finnish population no association was revealed between maternal nutrition and blood pressure in children. However, these early $20^{\text {th }}$ century cohort studies was heavily criticized to be confounded by socio-economic and lifestyle factors postnatal period until the measurement of outcome ${ }^{13}$. The large part of evidence supporting the fetal origin hypothesis of obesity, diabetes and cardiovascular disease was largely coming from animal studies ${ }^{2}$. The evidence from intervention studies was scare, whereas, the association observed in epidemiological studies ${ }^{2,4}$ was inconclusive. Until we posses established evidence from repeated RCTs the fetal origins hypothesis remain to be a battleground for debate. Therefore, a real outcome might be less than optimal outcome we might want, that is some of the children from mothers who implement the lifestyle recommendation would be overweight or obese and having hypertension at the age of 10. The results of an RCT targeting women with mild GDM between 24-34 weeks gestation with predominantly dietary interventions and blood glucose monitoring fail to show significant difference in BMI of the children at age 4 to 5 years old ${ }^{10}$. Upon this null effect size, the author argues that they can not adjust the results for possibility the effect of post natal factor that determine the height and weight of the child for example the food eaten and physical exercise, overpower the effect of treating GDM during pregnancy ${ }^{10}$. Furthermore the authors argue that the effect of fetal origin of disease might be takes more time to occurs by citing the finding from Pima Indian study that showed association of maternal GDM with the offspring BMI after the age of 9 , but not before ${ }^{10}$. We believe that many factors, especially external factors such as the role of obesogenic environments ${ }^{14,15}$, child physical activity ${ }^{16}$ and caloric dense diet ${ }^{17}$ of the child post-natal until the age of 10 might be deviate our optimal results.

\section{CONCLUSION}

The argument that nutrition from the time of conception is believed to affect the biological health of children in the future is increasingly stronger in the current literature althought evidence of experimental research results still need to be accumulated to ensure the truth.

\section{ACKNOWLEDGEMENT}

The author thanks Dr. Mark Haub of Kansas State University for giving him this question during his preliminary exam for doctoral candidature at Kansas State University. 


\section{REFERENCE}

1. Ornoy A. Prenatal origin of obesity and their complications: Gestational diabetes, maternal overweight and the paradoxical effects of fetal growth restriction and macrosomia. Reproductive toxicology. 2011;32(2):205-12.

2. Rasmussen KM. The "fetal origins" hypothesis: Challenges and opportunities for maternal and child nutrition. Annu Rev Nutr. 2001;21(1):73-95.

3. Holt RIG. Fetal programming of the growth hormone-insulin-like growth factor axis. Trends in endocrinology and metabolism. 2002;13(9):392-7.

4. Szostak WÄ̈gierek D, Szamotulska K. Fetal development and risk of cardiovascular diseases and diabetes type 2 in adult life. Med Wieku Rozwoj. 2011;15(3):203-15.

5. McGowan C, Walsh J, Byrne J, Curran S, McAuliffe $F$. The influence of a low glycemic index dietary intervention on maternal dietary intake, glycemic index and gestational weight gain during pregnancy: A randomized controlled trial. Nutrition journal. 2013;12(1):140.

6. Gardner B. Changing diet and physical activity to reduce gestational weight gain:

A meta-analysis. Obesity reviews. 2011;12(7):E602-20.

7. Procter S. Position of the academy of nutrition and dietetics: Nutrition and lifestyle for a healthy pregnancy outcome. Journal of the Academy of Nutrition and Dietetics. 2014;114(7):1099-1103.

8. Campbell F, Johnson M, Messina J, Guillaume L, Goyder E. Behavioural interventions for weight management in pregnancy: A systematic review of quantitative and qualitative data. $B M C$ Public Health. 2011;11:491.
9. Streuling I, Beyerlein A, von Kries R. Can gestational weight gain be modified by increasing physical activity and diet counseling? A meta-analysis of interventional trials. Am J Clin Nutr. 2010;92(4):678-87.

10. Gillman M. Effect of treatment of gestational diabetes on obesity in the next generation. Diabetes Care. 2010;33(5):964-968.

11. Ramakrishnan U. Effect of multiple micronutrient supplementation on pregnancy and infant outcomes: A systematic review. Paediatr Perinat Epidemiol. 2012;26 Suppl 1(1):153-167.

12. Roy $S$, Sable $P$, Khaire A, Randhir K, Kale $A$, Joshi S. Effect of maternal micronutrients (folic acid and vitamin B12) and omega 3 fatty acids on indices of brain oxidative stress in the offspring. Brain Dev. 2014;36(3):219-27.

13. Gillman MW, Rich Edwards JW. The fetal origin of adult disease: From sceptic to convert. Paediatr Perinat Epidemiol. 2000;14(3):192-3.

14. Popkin BM. Synthesis and implications: China's nutrition transition in the context of changes across other low- and middleincome countries. Obesity reviews. 2014;15 Suppl 1:60-7.

15. Kumanyika S. Environmental influences on childhood obesity: Ethnic and cultural influences in context. Physiology behavior. 2008;94(1):61-70.

16. Guthold R, Cowan M, Autenrieth C, Kann L, Riley L. Physical activity and sedentary behavior among schoolchildren: A 34country comparison. I Pediatr. 2010;157(1):43-49.e1.

17. Ebbeling $\mathrm{C}$, Feldman $\mathrm{H}$, Chomitz V, et al. A randomized trial of sugar-sweetened beverages and adolescent body weight. $N$ Engl J Med. 2012;367(15):1407-1416. 